\title{
Is the presence of uterine fluid a reliable indicator of endometrial inflammation?
}

\author{
Emílio Viegas Cásseres de Borba', Giovani Casanova Camozzato', Eduardo Malschitzky², Ivan Cunha Bustamante-Filho ${ }^{1,4}$, Anelise \\ Afonso Martins ${ }^{3}$, Rodrigo Costa Mattos ${ }^{7}$ and Adriana Pires Neves ${ }^{3}$
}

REPROLAB, Faculdade de Veterinária, UFRGS, Porto Alegre ${ }^{1}$, Curso de Medicina Veterinária, ULBRA, Canoas², Faculdade de Zootecnia, Unipampa, Dom Pedrito $^{3}$ and Centro Universitário UNIVATES, Lajeado ${ }^{4}$ Brazil

\begin{abstract}
Summary
Endometrial cytology is a fast and reliable way to assess the uterus status breeding or insemination. Ultrasound examination may detect the presence of uterine luminal fluid (IUF), which suggests susceptibility to persistent endometritis. The aims of this study were (1) to test three different protocols for endometrial cytology sampling and (2) to compare ultrasonographic evaluation and uterine cytology for the diagnostic of uterine inflammation. Experiment 1 - Twenty mares were submitted to one of the following protocols for endometrial cytology: (i) uterine flush $-60 \mathrm{ml}$ PBS were infused into the uterus via cuffed catheter. The fluid was recovered and centrifuged at 1,000 rpm $\times 5$ min. The pellet was re-suspended in $0.5 \mathrm{ml}$ of fetal calf serum. This suspension was spread onto a microscope slide and stained with DiffQuik.; (ii) uterine swab - A guarded sterile cotton swab was used to obtain the endometrial sample. The swab was rolled back onto a clean microscope slide and the specimen fixed and stained with Diff-Quik; (iii) cervical brush - similar to the previous procedure, but using a cervical brush. In the swab and cervical brush protocols, cytology was considered negative when no PMN (polymorphonuclear cell) were detected in slides. Experiment 2: Seventy-two mares were used to assess the effectiveness of two methods for diagnosis of endometrial inflammation: (a) ultrasonographic determination of IUF; (b) endometrial cytology a using cervical brush. In experiment 1 , no difference was observed between the three methods analyzed. In Experiment 2, a significant $(p<0.001)$ number of mares without IUF but positive for endometrial cytology $(n=19,36.5 \%)$ was found. It can be concluded that endometrial cytology of the estrous mare is a valuable and quick procedure that should be performed for the diagnosis of endometritis.
\end{abstract}

Keywords: mares; endometritis; inflammation; cytology, reproduction

\section{Ist das Auftreten uteriner Flüssigkeit ein zuverlässiger Indikator für eine Entzündung des Endometriums?}

Die zytologische Untersuchung des Endometriums ist eine schnelle und zuverlässige Methode, um den uterinen Status bei der Bedeckung oder Besamung zu beurteilen. Mit Hilfe der Sonographie sind intrauterine Flüssigkeitsansammlungen zu diagnostizieren, die auf eine Empfindlichkeit gegenüber einer persistierenden Endometritis hinweisend können. Ziel dieser Untersuchung ist es, erstens drei verschiedene Verfahren für die zytologische Probenentnahme zu testen und zweitens die sonographischen Befunde mit den zytologischen Ergebnissen in Hinblick auf eine Entzündung des Uterus zu vergleichen. Experiment 1: 20 Stuten standen für folgende zytologische Verfahren zur Verfügung: 1. Uterusspülung -60 ml PBS wurde mittels eines bedeckten Katheters in den Uterus infundiert. Die Flüssigkeit wurde zurück gewonnen und 5 Minuten bei 1000 Umdrehungen pro Minute zentrifugiert, danach das Pellet in 0,5 ml fetalem Kälberserum resuspendiert. Anschließend erfolgte das Ausstreichen der Suspension auf einem Objektträger und Färben mit Diff-Quik. 2. Tupferprobe - Zur Probenentnahme kam ein geführter steriler Baumwolltupfer zum Einsatz. Der Tupfer wurde auf einem sauberen Objektträger ausgestrichen, das Präparat fixiert und mit Diff-Quik gefärbt. 3. Zervikale Bürstenprobe - ein ähnliches Verfahren wie unter 2 beschrieben, jedoch unter Einsatz einer Bürste. Für die Protokolle der Tupfer und Bürstenproben galt das Ergebnis der Zytologie negativ, wenn keine neutrophilen Granulozyten (PMN) nachgewiesen werden konnten. Experiment 2: 72 Stuten standen zur Verfügung, um die Effektivität der beiden Methoden Zytologie (mittels Zervikalbürste) und Sonographie (Vorhandensein intrauteriner Flüssigkeit) zu beurteilen. Im Ergebnis bestand kein signifikanter Unterschied zwischen den drei getesteten zytologischen Untersuchungsverfahren. Eine signifikante Anzahl ( $p<0,001)$ von Stuten, bei denen keine intrauterine Flüssigkeit festgestellt werden konnte, wies ein positives zytologisches Ergebnis auf ( $n=19,36,5 \%$ ). Zusammenfassend wird festgestellt, dass die endometriale Zytologie bei östrischen Stuten ein wertvolles und schnelles Verfahren ist, das für die Diagnose einer Endometritis eingesetzt werden sollte.

Schlüsselwörter: Stute, Endometritis, Entzündung, Zytologie, Reproduktion

\section{Introduction}

Several diagnostic tools have been developed to check the reproductive soundness in mares as rectal palpation, ultrasound examination, or more invasive methods as endometrial cytology and biopsy. The endometrial cytology is a fast and reliable way to assess the uterus status during quick-response situations, e.g. immediate breeding or insemination (Riddle at al. 2007). It diagnoses the presence of inflammatory cells in the uterine lumen and helps practitioners to make better decisions about treatments. Another relevant procedure is the ultrasound examination that evaluates the presence of uteri- ne luminal fluid (IUF). The causes for the IUF accumulation are unclear but it could be an excessive production of fluid; a delay in physical clearance by uterine contractility; or a limited reabsorption by lymphatic vessels; or even combination of these three mechanisms (Sertish 2007).

The presence of free IUF before breeding suggests susceptibility to persistent endometritis (Pycock and Newcombe 1996, Maloufi et al. 2002, Brinsko et al. 2003). This fluid is sterile but it may act as a culture medium for bacteria that enter the uterus during mating or insemination, and may also be spermicidal (McKinnon et al. 1993). The objectives 
of this study were (1) to test three different protocols for endometrial cytology sampling and (2) to compare ultrasonographic evaluation and uterine cytology for the the diagnostic of uterine inflammation.

\section{Materials and Methods}

Cycling mares ( 5 to 21 years-old) were regularly examined by rectal palpation and ultrasonography (Aloka SSD-500V; Aloka, Wallingford, CT, USA) during 2009-10 breeding season. During this routine, follicular growth, uterine edema and the presence of IUF were recorded. The IUF was characterized by hypoechoic areas larger than $10 \mathrm{~mm}$ diameter in the uterine lumen (Adams et al. 1987).

\section{Experiment 1}

Twenty mares presenting one $>35 \mathrm{~mm}$ follicle and uterine edema were examined for IUF, followed by endometrial cytology performed by three different protocols: (i) uterine flush $60 \mathrm{~mL}$ PBS (DMPS Flush, Nutricell Nutrientes Celulares, Campinas-SP) were infused into the uterus via cuffed catheter (32FR-75cc, Bioniche Animal Health, Belleville, ON, Canada). The fluid was recovered as much as possible and centrifuged at 1,000 rpm x $5 \mathrm{~min}$. The pellet was re-suspended in $0.5 \mathrm{~mL}$ of fetal calf serum (Soro Fetal Bovino, Nutricell Nutrientes Celulares, Campinas-SP). This suspension was spread onto a microscope slide and stained with Diff-Quik (Panótico Rápido, Laborclin Ltda., São José dos Pinhais, Brazil) according to Mattos et al. (1984). The presence of $>2 \%$ neutrophils was considered positive (Ball et al. 1988)

\section{Uterine swab}

A guarded sterile cotton swab (Rayswab, Alamar Tecno-científica Ltda., Brazil) was used to obtain the endometrial sample. After passage through the cervix into the uterine lumen via a sterile speculum, the swab was scrubbed against the endometrium, retracted into the sheath and removed from the uterus. The swab was rolled back onto a clean microscope slide and the specimen fixed and stained with Diff-Quik.

\section{Cervical brush}

Similar to the previous procedure, but using a cervical brush (Cytobrush, Fishers Scientific, Nepean, Ontario), according to Alvarenga and Mattos (1990). In the swab and cervical brush protocols, cytology was considered negative when no PMN (polymorphonuclear cell) were detected in slides.

\section{Experiment 2}

Seventy-two mares were used to assess the effectiveness of two methods for diagnosis of endometrial inflammation: (a) ultrasonographic determination of IUF (Adams et al. 1987) and (b) endometrial cytology a using cervical brush (Alvarenga and Mattos 1990). The Chi-square test (GraphPad Prisma 5, LaJolie, CA) was used to analyze the data from both experiments.

\section{Results}

In experiment 1, no difference was observed between the three methods analyzed. All mares with positive cytology presented more than one PMN in each observed slide field. Results are shown on Table 1.

The correlation between presence of IUF and endometrial cytology was assessed in Experiment 2. A significant number of mares without IUF but positive for endometrial cytology were found, as shown in Table 2.

\section{Discussion}

The present study showed that endometrial cytology is a fundamental tool to assess uterine soundness, regardless of the protocol. The use of a guarded swab or brush or low-volume uterine flush yielded similar results. For reasons of conve-

\begin{tabular}{|c|c|c|c|c|}
\hline \multirow{3}{*}{ Endometrial cytology } & \multirow{2}{*}{\multicolumn{2}{|c|}{ Positive }} & \multirow{2}{*}{\multicolumn{2}{|c|}{ Negative }} \\
\hline & & & & \\
\hline & $\mathrm{N}$ & $\%$ & $n$ & $\%$ \\
\hline Uterine flush & 10 & 50 & 10 & 50 \\
\hline Uterine swab & 10 & 50 & 10 & 50 \\
\hline Cervical brush & 11 & 55 & 9 & 45 \\
\hline
\end{tabular}

$\mathrm{X}^{2}=0.1335 ; p=0.935$

Table 2 Endometrial cytology from mares with or without uterine fluid before breeding / Endometriale Zytologie von Stuten mit und ohne intrauterine Flüssigkeitsansammlung vor der Bedeckung

\begin{tabular}{lcccc}
\hline & \multicolumn{3}{c}{ Intra-uterine Fluid } \\
\cline { 2 - 5 } Endometrial Cytology & \multicolumn{2}{c}{ Presence } & \multicolumn{3}{c}{ Absence } \\
\hline Positive & $\mathrm{n}$ & $\%$ & $\mathrm{n}$ & $19^{\mathrm{a}}$ \\
Negative & $15^{\mathrm{a}}$ & 75 & 36.5 & $33^{\mathrm{b}}$ \\
\hline
\end{tabular}

Different superscripts indicate significance: $a$ and $b, X^{2}=26.72(p<0.001)$ 
nience, the cervical brush was the chosen method to use in Experiment 2. A discrepancy was found between the two methods evaluated for diagnosis of endometritis in mares. The occurrence of $36.5 \%$ cytology positive mares with no IUF suggests a higher accuracy of this diagnostic procedure in comparison to US examination for IUF. Probably, in some mares, endometrial inflammation occurs with intraluminal fluid lower than $10 \mathrm{~mm}$ and, in these cases, cytology is the best option for a prompt and precise diagnosis. In five cases (25\%), the presence of IUF was not associated with the presence of PMNs, which means diagnosis would be false-positive if based on US examination alone. This might happen for several reasons: inaccuracy of the endometrial cytology sampling technique, or the presence of strong physiological edema, since mares were examined in estrus, or bacterial infection with E. coli or Pseudomonas, which are not commonly associated with positive cytology (LeBlanc 2010).

In conclusion, endometrial cytology of the estrous mare is a valuable and quick procedure that should be performed for the diagnosis of endometritis. Furthermore, a finding of IUF $<10 \mathrm{~mm}$ using only ultrasound may not be conclusive evidence of inflammation.

\section{Acknowledgements}

The authors would like to thank to Prof. Dr. Sérgio I. dos Santos for the statistical work; to Luciana Meirelles Richer (DVM) for the English language revision; and to the farms which provided the animals.

\section{References}

Alvarenga M. A. and Mattos C. I. (1990) Utilização da escova ginecológica na coleta de material endometrial de éguas. Arq. Bras. Med. Vet. Zootec. 42, 67-68

Adams P., Kastelic J. P., Bergfeld D. R. and Ginther O. J. (1987) Effect of uterine inflammation and ultrasonically-detected uterine pathology on fertility in the mare. J. Reprod. Fert. Suppl. 35, 445-454
Ball B. A., Shin S. J., Patton V. H., Lein D. H. and Woods G. L. (1988) Use of a low-volume uterine flush for microbiologic and cytologic examination of the mare's endometrium. Theriogenology 29, 1269-1283

Brinsko S. P., Rigby S. L., Varner D. D. and Blanchard T. L. (2003) A practical method for recognizing mares susceptible to post breeding endometritis. In: Proceedings of the 49 th Ann. Conv. Am. Assoc. Equine Pract., 363-365.

LeBlanc M. M. (2010) Advances in the Diagnosis and Treatment of Chronic Infectious and Post-Mating-Induced Endometritis in the Mare. Reprod Dom Anim 45 (Suppl. 2), 21-27

Maloufi F., Pierson R., Otto S., Ball C. and Card C. E. (2002) Mares susceptible or resistant to endometritis have similar endometrial echographic an dinflammatory cell reactions at 96 hours after infusion with frozen semen and extender. In: Proceedings of the 48th Annual Conv American Association Equine Practitioners, 51 57

McKinnon A. O., Voss J. L. and Squires E. L. (1993) Diagnostic ultrassonography. In McKinnon A. O., Voss J. L. (Ed): Equine Reproduction. Lea \& Febiger, Philadelphia USA, pp. 266-302

Pinto C. R. F. (2009) Diseases of the uterus. In. Robinson, N.E., Sprayberry, K.A.(Eds) Current Therapy in Equine Medicine 6. Saunders, St Louis, USA, pp. 769-776

Pycock J. F. and Newcombe J. R. (1996) The relationship between intraluminal uterine fluid, endometritis and pregnancy rate in the mare. Equine Pract. 18, 19-22

Riddle W. T., LeBlanc M. M. and Stromberg A. J. (2007) Relationships between uterine culture, cytology and pregnancy rates in a Thoroughbred practice. Theriogenology 68, 395-402

Sertish P. L. (2007) Intrauterine Diagnostic Procedures. In: Samper J., Pycock J., McKinnon A.O. Current Therapy in Equine Reproduction. Saunders, St Louis, USA, 36-43 